\section{ラクヒ一合宿の体育医学的研究（第 1 報）}

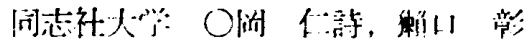
游辺垌一，渡过博之

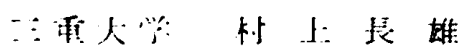

食ての競技において，できるだけ良いコンデイション で試命にのぞむことが望ましいのは当然のことである. この為にはラクビーのような団体プレーでは，選手個々 の状態を考之ながらチーム全体としての状態を考慮する 必要がある。一般に合宿練習などでは，生活環境—定 し，個々の選手の状態む統一した観察で判断して大差な いよらである．血王や脈拍の低下は代謝の低下に通ずる ものがあり，筋力もこのような時期には低下しているこ

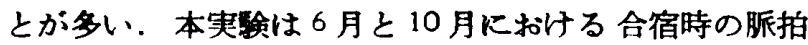
数, 血王值, 肺活量, 掩力, 脚力及び 2.3 の尿組成の消 長について検討したるので，被検者は本学ラクビー部員 9 名，每朝 8 時に測定を行い，その平均値を求めたもの である.そしてこれらの成結より能後の試合計画の资料 とする予定であるが，実際の試合に打ける成綪について の結果は次報に待つこととして，今回は得られた測定傎 及びそれらの意義について報告する。

1. 6 月 1 週間合宿時の影紫——本合宿はオフシーズ ンであり，春手練習は 5 月末日に釉光，部員個々が軽度 のトレーニングを行つていたのみである．脈拍数は第 3 日に最低を示し，Ifl值は第 2，3，4 日に低值を示した。 肺活量は第 3, 4 両日に谷を示し，脚力は第 3 日に最低值 あ示し，暒力は右左共に第 4 日に最低であつた，尿量は 第6.7 日の低值と第 3.4 両日にも一つのくぼみがみら

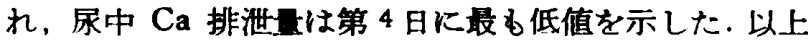
より肺活量，脚力,捚力などの筋力は第 3，4両日に最低を 示しているのがわかる，一方脈拍数は第 3 日，血圧值は 第 4 日に低值を示しており，筇力の低下を示す時期に は脈拍数及び血压值る低值を示すことがわかる．また，

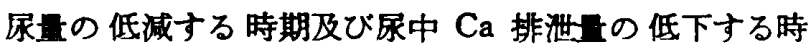
期には一般に筇力の低下む著しくなるが，尿量は第 3，4 両日でくばみを示し，尿中 Ca 排泄量は第 4 日に著し い行が元られ，筋力低下の時期と一政していた，以上上

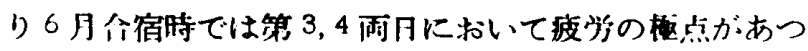

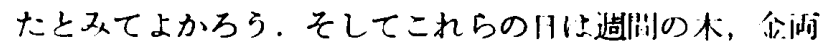
明䭪にわたることが注月された。

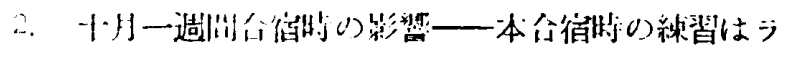
クビーのシーズンに入り相当強化されたものである。判

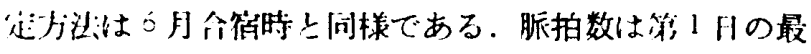
低值に沃いで第 7 日にも低值を示した。肺活量は第1日 の最低值も除くと第 5 日低値を示した。脚力む第 1 日に 最低值を示し，第 5 日に一つの谷そして第7日にも低倠 を示した，握力右は第 5 日の谷及び第 7 日に最低值，暒 力左は第 6.7 日に低值を示した. 次に尿量は第6.7 日に 低值を示し，我中 $\mathrm{Ca}$ 排泄第 6,7 両日に低值を示 した.これらの成綪よりみて10月合宿時には第 5 日亦 は第 7 日に最も疲学度の強い点があつたものと考えられ る。これは6月の成續とや〉異る点がみられるが，この 相違について以下の上らな考察ができる。

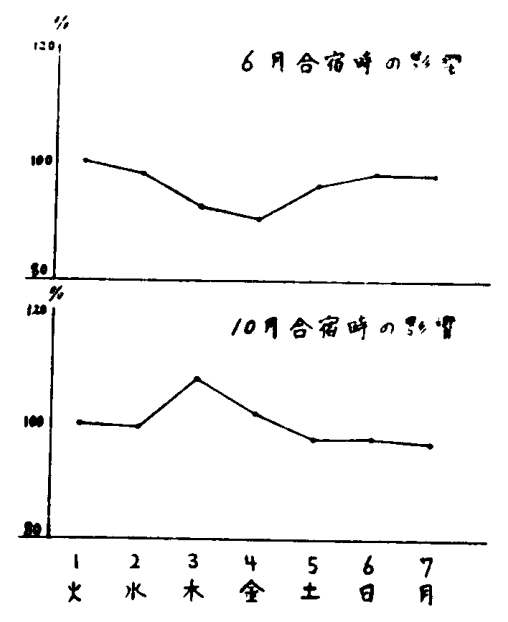

このグラフは脈拍数，血圧值，肺活量，脚力, 捚力, 尿量及び尿中 $\mathrm{Ca}$ 排泄量の第 1 日の值を 100 として夫ヶ の\%を求め, 夫々の相加平均俌を图に表はしたものであ る.

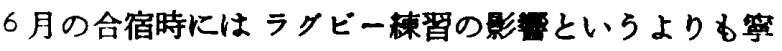
ろ学生生活の 影敏が著しく現われているすのとみてよ く，実漈我々の生活に扎いてす木，金両日に疲労状照の 顕著であるのと一致するようである. 而し10月の摍

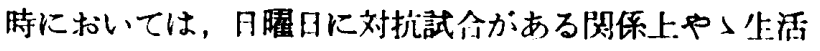

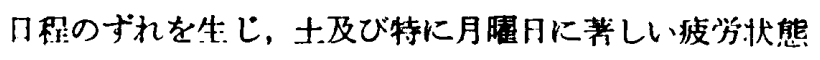

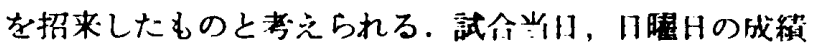

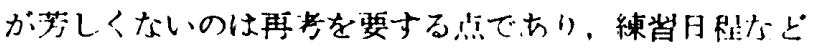

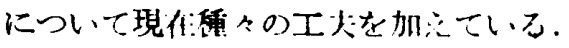

